\title{
The influence of protected area outreach on conservation attitudes and resource use patterns: a case study from western Tanzania
}

\author{
Christopher M. Holmes
}

\begin{abstract}
This case study investigates the conservation attitudes of two ethnic groups, horticulturalist Pimbwe and agropastoralist Sukuma, living around Katavi National Park (KNP) in western Tanzania, East Africa. Specifically, interest in degazetting KNP was examined (as a reflection of attitude towards the Park) relative to type and extent of KNP outreach, wildlife-related problems, household wealth and residency status. Reported attitudes were then related to fuelwood extraction patterns. Attitudinal surveys showed that a lack of KNP outreach (i.e. village-level services and visits by KNP staff) and increased land wealth and shorter residency time were associated with increased interest in seeing KNP degazetted. However, after controlling for ethnicity only recognition of village-level Park services was still associated with positive attitudes towards KNP. People
\end{abstract}

recognizing KNP services also demonstrated more ecologically sustainable wood extraction methods. These results suggest that while attitudinal studies seem to be a logical step towards making informed decisions about the effectiveness of protected area outreach, relating such outreach to behavioural changes in resource use through attitudinal assessment is a greater challenge, requiring a clear understanding of the relative influence of socioeconomic and cultural factors.

Keywords Attitudes, community conservation, fuelwood, Katavi National Park, protected area outreach, Tanzania.

This paper contains supplementary material that can only be found online at http://journals.cambridge.org

\section{Introduction}

Incorporating local communities into conservation activities is an alternative to the more traditional exclusionary 'fences and fines' approach to protecting biological diversity (Kiss, 1990; Wells et al., 1992; Western \& Wright, 1994; Alpert, 1996; Hulme \& Murphree 1999, 2001). Implementing such initiatives has become so commonplace in the last decade that they are now considered mainstream conservation practice (Inamdar et al., 1999), and touted as the impetus of 'new conservation' (Hulme \& Murphree, 1999). However, as these initiatives become more common, so does the scrutiny of their logic and effectiveness (Adams \& Hulme, 2001; Kothari, 2001; Western, 2001). Severe critics argue that community conservation initiatives are fundamentally flawed because economic aspirations of rural populations are incompatible with sustainable resource use (Oates, 1995, 1999; Barrett \& Arcese, 1995, 1998). More moderate criticism focuses on a lack of understanding

Christopher M. Holmes, Institute for the Conservation of Tropical Environments (ICTE), Department of Anthropology, SUNY Stony Brook, Stony Brook, NY 11794-4364, USA. E-Mail: cholmes@ucdavis.edu

Received 12 June 2002. Revision requested 16 December 2002. Accepted 30 April 2003. of the resource use interests of local populations, which is critical to effective integrative conservation (Gibson \& Marks, 1995; Noss, 1997; Hackel, 1999; Songorwa, 1999; Newmark \& Hough, 2000).

Focusing on this need to better understand resource use interests, numerous studies have employed surveys to characterize community attitudes towards conservation and identify factors associated with increased commitment to conservation efforts (Table 1). The supposition was that resource use variation would be reflected in people's attitudes towards conservation (Infield, 1988; Gibson \& Marks, 1995; Songorwa, 1999; Newmark \& Hough, 2000), and that careful assessment of attitudes could serve to guide effective community conservation initiatives (Parry \& Campbell, 1992; Fiallo \& Jacobson, 1995; Infield \& Namara, 2001). Infield \& Namara (2001) went as far as to suggest that attitudes can be useful surrogates for behaviour in situations where assessing behavioural changes is difficult. Yet of the 18 studies identified in Table 1 only Abbot et al. (2001) and Adams \& Infield (2001) considered the effects of conservation initiatives on attitudes and concomitant behavioural changes. While both these studies attributed improved attitudes to community conservation initiatives, the authors were careful to note that circumstances leading to reported behavioural changes were less clear. 


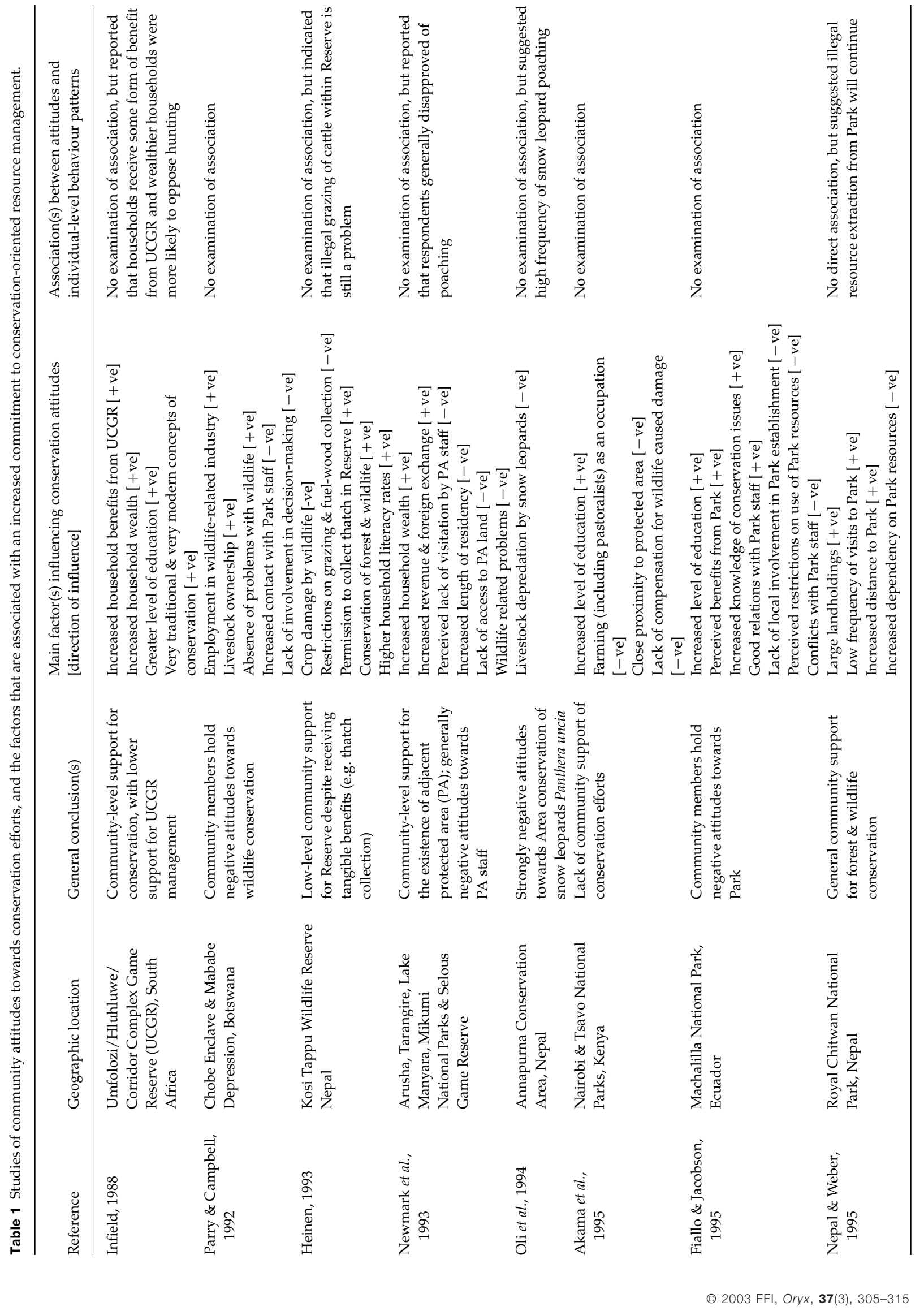




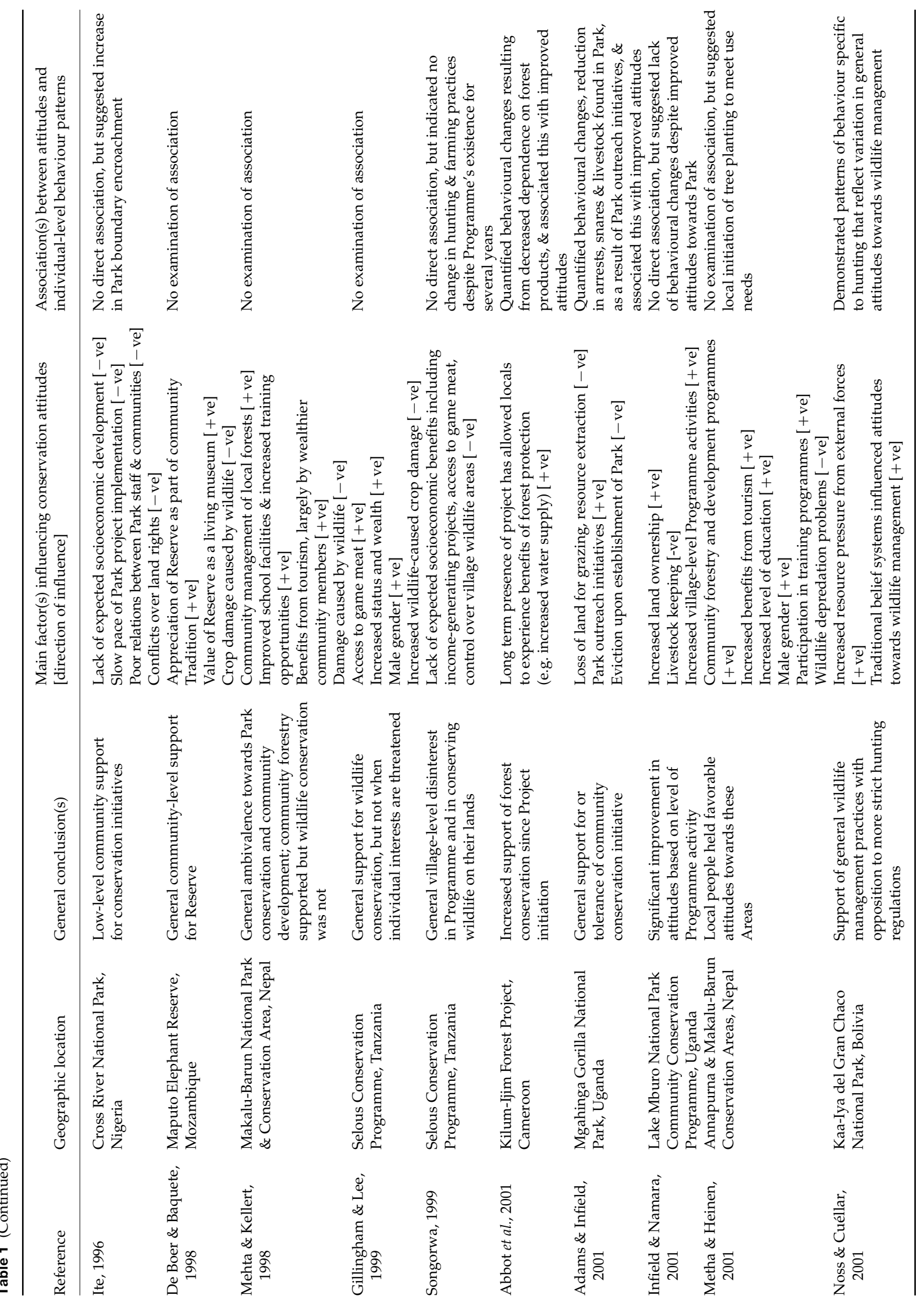


These efforts notwithstanding, important questions remain concerning the circumstances under which conservation attitudes reflect resource use patterns. These include determining the relative effects of socioeconomic and cultural factors on outreach recognition and associated attitudes, and how attitudes are manifested in resource utilization. To address these questions this case study explored the relationship between attitudes and wood-use practices in three communities living adjacent to Katavi National Park (KNP), Tanzania. I investigated associations between a desire to see KNP degazetted, as a reflection of attitude towards the Park, and (i) recognition of Park services and staff visits, (ii) exposure to wildlife-related problems, and (iii) household socioeconomic status. The relationship between attitudes towards KNP and household wood-use was then examined to determine how well attitudes reflected behaviours. The following prediction was made: if conservation attitudes accurately reflect patterns of resource use then households expressing positive attitudes should exhibit more ecologically sustainable wood extraction methods.

\section{Methods}

\section{Study location}

Gazetted in 1974, Katavi National Park is located in western Tanzania, East Africa in the northern Rukwa Valley. No settlements and no form of resource use or extraction are tolerated within KNP's borders. Extended in 1998 to $c .4,500 \mathrm{~km}^{2}$, Katavi is now the third largest national park in Tanzania. Large mammal biomass in KNP is estimated at $23,139 \mathrm{~kg} \mathrm{~km}^{-2}$, with buffalo Syncerus caffer occurring at the largest average densities $\left(22 \mathrm{~km}^{-2}\right)$, and zebra Equus burchelli, hippopotamus Hippopotamus amphibius, waterbuck Kobus ellipsiprymnus and impala Aepyceros melampus all occurring at densities $>3$ individuals $\mathrm{km}^{-2}$ (Caro, 1999a). Vegetation composition of KNP is largely dry miombo woodland, dominated by Acacia, Combretum, Julbernardia, Pterocarpus and Terminalia tree species. Southwards into the Open Area separating the Park from neighboring villages the miombo woodland gives way to mixed acacia woodland, dominated by Acacia tortilis, Acacia polyachantha, Grewia bicolor and Markhamia acuminata.

While management efforts centre on protecting the Park's large mammal fauna, KNP also provides a unique opportunity to conserve large tracts of intact miombo woodland, an increasingly threatened habitat (Rodgers, 1996). However, human presence in the area is expanding; there has been a $5.7 \%$ per annum growth rate in the Rukwa region over the past 30 years (Tanzania, 1991). Consequently, with all households relying on wood as their sole energy source for cooking and heating, wood resources in the immediate surroundings of KNP are subject to heavy extraction rates. This combination of great biological diversity, dependence on local wood resources for subsistence use, and encroaching human populations makes the assessment of human impact in this area a high-priority conservation issue (Caro, 1999a, b).

\section{Study system}

This study was conducted in the villages of Kibaoni, Manga and Mirumba, situated 9.0, 10.5, and $8.5 \mathrm{~km}$ respectively from the southern border of KNP (Fig. 1). The populations of these villages are largely comprised of two ethnic groups, the Pimbwe and Sukuma. While the Pimbwe and Sukuma live in close proximity to each other and interact on a daily basis, they are two culturally distinct ethnic groups (Willis, 1966; Brandström, 1986; Paciotti \& Hadley, in press) with distinct subsistence economies and household-level dynamics.

The Pimbwe are the original inhabitants of the Rukwa valley, historically relying on subsistence hunting in the area that is now KNP. Since the Park's establishment, Pimbwe have shifted to largely practising subsistence horticulture. Additional subsistence activities include fishing and honey gathering, with some individuals generating income through off-farm activities including carpentry and the sale of processed building wood (pers. obs.).

The Sukuma are agropastoralists, who settled in the Rukwa valley over the past 30 years. Generally labelled as environmentally insensitive, relatively little is known of the factors influencing Sukuma resource use patterns. They are generally mobile, staying in a single location for a relatively short time, with length of stay often determined by availability of quality grazing for their cattle. In the Rukwa valley Sukuma live on the periphery of already established Pimbwe villages, and concentrate on both cattle herding and large-scale agriculture.

\section{Field methods and data collection}

Data were collected during three 5-month periods from July to November 1999, 2000 and 2001. Prior to data collection, research protocols and draft survey forms were reviewed and approved by the Committee on the Use of Human Subjects, University of California, Davis, USA, and permission to conduct the research in Tanzania was granted by officials at the Tanzania Commission for Science and Technology. Eighty households (40 per ethnic group) in each village were randomly chosen from lists generated through meetings with village 


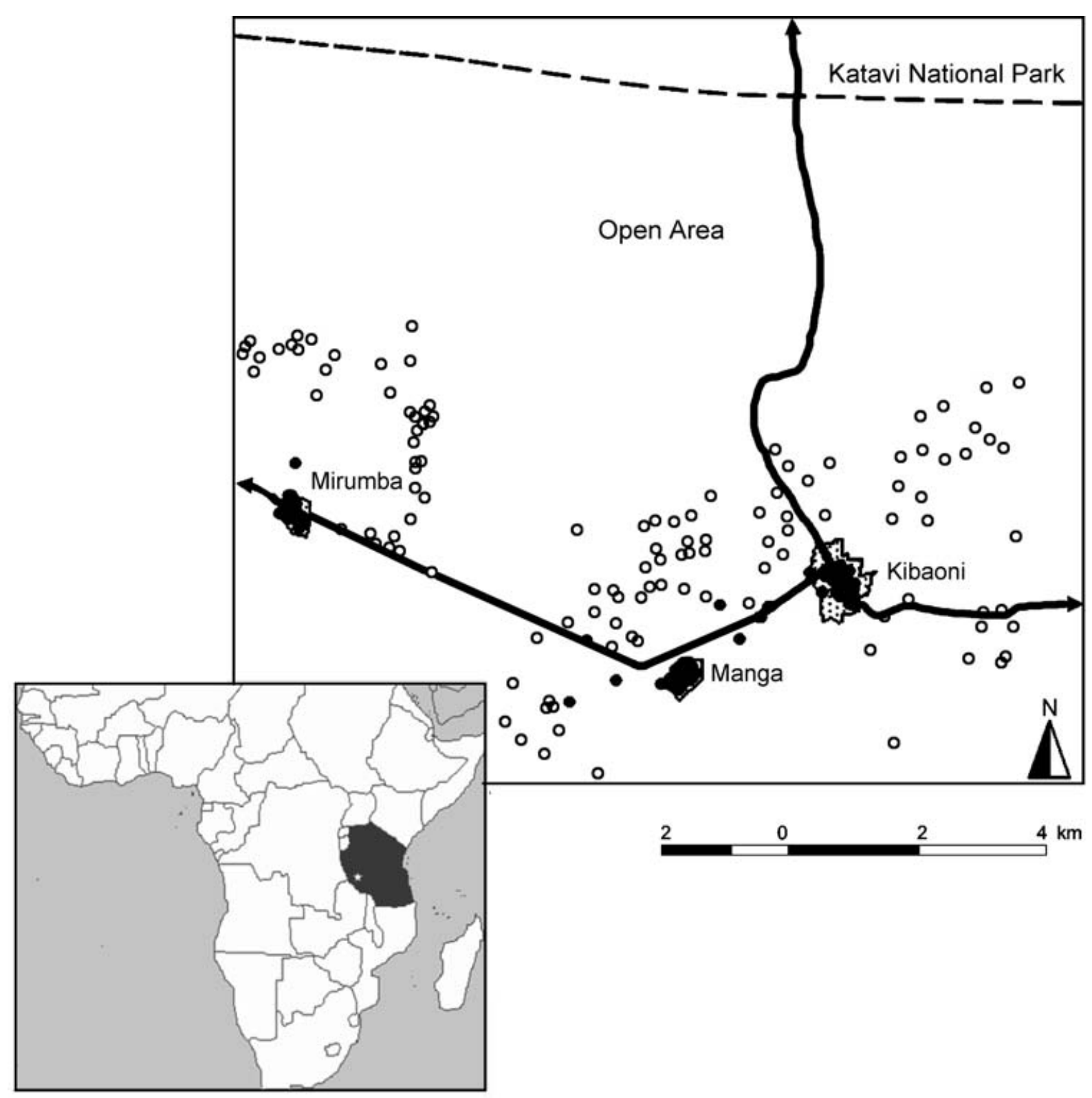

Fig. 1 The location of the three study villages relative to the southern boarder of Katavi National Park, represented as a hatched line. Open and filled circles are the 120 surveyed Sukuma and Pimbwe households, respectively. Thick lines denote primary gravel roads. The star on the inset map indicates the location of the study area in the Rukwa Region of Western Tanzania.

officials, and served as representative subset for each village. This large sample was chosen to ensure adequate power in subsequent analyses (Kirk, 1995).

During June-November 1999 structured interviews, using both closed and open-ended questions relating to residency, land ownership, and wood use (Appendix 1) were conducted in each household. This survey served to quantify household wood-use, and identify factors influencing patterns of wood-use. In addition, the number of individuals per household was recorded, and a list of pre-identified material assets (bicycle, bicycle pump, plough, axe, radio, wrist watch and flashlight) owned by each household was compiled to generate a wealth score based on the relative value of each asset as a function of its scarcity (Morris et al., 1999).

During June-November 2000 individuals were followed as they searched for fuelwood. This was done for a subset of 72 households (12 households per ethnic group per village). One purpose of this was to record the condition of trees from which wood was collected, 
in order to qualify extraction methods; collecting live branches or felling live trees was classified as less ecologically sustainable than collecting fallen dead branches or collecting from a dead tree that neither the collector nor a family relative felled.

During June-November 2001, households were revisited and interviewed about their attitudes towards KNP. This survey consisted of a series of closed and open-ended questions relating to perceptions of KNP, perceived levels of Park outreach, and wildlife conflicts (Appendix 2). This allowed determination of degree of Park and village interaction. I conducted all interviews during this study in Swahili, with a local assistant translating into Sukuma as necessary. This, in addition to my presence in the study area since 1998, and my involvement as a local community member, minimized potential response bias. SPSS Version 10.0 (SPSS Inc., Chicago, USA) was used for all statistical analyses.

\section{Results}

\section{Community attitudes towards Katavi National Park}

Of 240 households selected in 1999, 201 were revisited in 2001 and interviewed about their attitudes towards $\mathrm{KNP}$. As a measure of attitude towards KNP, respondents in the 2001 survey were asked the open-ended question: "How would you feel if Katavi National Park was degazetted?" Fifty percent $(n=100$; Pimbwe $=72$, Sukuma $=28$ ) responded that degazetting KNP would be wrong, 44\% ( $n=88$; Pimbwe $=25$, Sukuma =63) supported degazetting, 4\% ( $n=9$; Pimbwe =5, Sukuma =4) had no opinion, and $2 \%(n=4 ;$ Pimbwe $=3$, Sukuma $=1)$ said KNP should only be reduced in size. For statistical analyses, respondents replying with "no opinion" $(\mathrm{n}=9)$ and those replying that KNP should not be degazetted but should be reduced in size $(n=4)$ were excluded. Overall, respondents' attitudes towards KNP did not differ among villages $\left(\chi^{2}=3.268\right.$, d.f. $\left.=2, P=0.195\right)$. However, attitudes differed significantly between ethnic groups ( $\chi^{2}=33.890$, d.f. $\left.=1, \mathrm{P}<0.001\right) ; 69 \%$ of Pimbwe respondents $(\mathrm{n}=72)$ said KNP should not be degazetted, compared to $29 \%$ of Sukuma respondents $(n=28)$. Table 2 lists the reasons respondents felt KNP should or should not be degazetted.

\section{Effects of outreach and wildlife on community attitudes}

To identify levels of interaction between KNP staff and local communities, respondents in the 2001 survey were asked "What types of service has your village received from KNP?" and "Have KNP staff ever visited your village?" Respondents who answered positively to the question of KNP staff visitation were then asked the follow-up question "For what reason(s) did KNP staff visit your village?" Fifty-four percent ( $n=108$; Pimbwe $=31$, Sukuma $=77$ ) said their village has not received any type of service from $\mathrm{KNP} ; 46 \%$ ( $\mathrm{n}=93$; Pimbwe $=75$, Sukuma $=18$ ) said their village had received some service (Table 3 ). Overall, respondents recognizing some form of service were less likely to support the degazetting of $\operatorname{KNP}\left(\chi^{2}=103.976\right.$, d.f. $=1$, $\mathrm{P}<0.001$; Table 4), with Pimbwe expressing a stronger tendency than Sukuma to recognize KNP services $\left(\chi^{2}=51.749\right.$, d.f. $\left.=1, \mathrm{P}<0.001\right)$. When asked about KNP staff visits, 73\% ( $\mathrm{n}=146$; Pimbwe $=93$, Sukuma $=53)$ said that KNP staff had visited their village, while $27 \%$ $(\mathrm{n}=55$; Pimbwe $=13$, Sukuma $=42)$ said their village had not been visited. Again, respondents that said KNP staff had visited their village were less likely to support the degazetting of $\mathrm{KNP}\left(\chi^{2}=12.063\right.$, d.f. $=1, \mathrm{P}=0.001$;

Table 2 Reasons reported by the Pimbwe and Sukuma ethnic groups for why Katavi National Park should or should not be degazetted.

\begin{tabular}{|c|c|c|c|}
\hline & Pimbwe \% $(n=101)$ & Sukuma \% $(n=100)$ & Overall $\%(n=201)$ \\
\hline \multicolumn{4}{|l|}{ KNP should not be degazetted } \\
\hline The village received benefits of some sort & 39.5 & 25.0 & 35.6 \\
\hline The Park protected wildlife from poachers & 28.9 & 32.1 & 29.8 \\
\hline The Park generated foreign revenue & 14.5 & 17.9 & 15.4 \\
\hline The Park protected Tanzania's resources & 11.8 & 21.4 & 14.4 \\
\hline The boundary should be reduced in size & 5.3 & 0.0 & 3.8 \\
\hline The Park protected the village from wildlife & 0.0 & 3.6 & 1.0 \\
\hline \multicolumn{4}{|l|}{ KNP should be degazetted } \\
\hline Increased access to land in general & 58.6 & 25.4 & 34.1 \\
\hline Increased access to land for grazing & 0.0 & 34.9 & 25.0 \\
\hline Increased access to land for farming & 17.2 & 19.0 & 18.2 \\
\hline Increased access to land for building & 0.0 & 9.5 & 6.8 \\
\hline KNP provides no benefits & 10.8 & 4.8 & 6.8 \\
\hline Ability to hunt animals & 13.8 & 1.6 & 5.7 \\
\hline Increased access to wood resources & 0.0 & 4.8 & 3.4 \\
\hline
\end{tabular}


Table 3 Services that the Pimbwe and Sukuma ethnic groups reported they receive from Katavi National Park.

\begin{tabular}{llcr}
\hline Services received from KNP Staff & Pimbwe \% $(\mathrm{n}=75)$ & Sukuma \% $(\mathrm{n}=18)$ \\
\hline School, health and / or water services & 44.0 & 33.3 & Overall \% $(\mathrm{n}=93)$ \\
Protecting wildlife from poachers & 17.3 & 27.8 & 1.9 \\
Protecting KNP's resources & 18.7 & 22.2 & 19.4 \\
No specific help & 12.0 & 0.0 & 18.3 \\
Work as day labourers & 1.3 & 0.0 & 1.1 \\
Bring village children to visit KNP & 1.3 & 0.0 & 1.1 \\
Bring game meat to the villagers & 1.3 & 0.0 & 1.1 \\
Provide transportation between villages & 1.3 & 0.0 & 1.1 \\
Buy local goods & 1.3 & 0.0 & 1.1 \\
Educate villagers about KNP & 1.3 & & 1.1 \\
\end{tabular}

Table 4 Reported interest by the Pimbwe and Sukuma ethnic groups in seeing KNP degazetted as related to recognition of village-level services received from Katavi National Park, village visits by Park staff, and exposure to wildlife-related problems.

\begin{tabular}{|c|c|c|c|c|c|c|c|}
\hline & & \multicolumn{6}{|c|}{ Degazetted Katavi National Park \% (n) } \\
\hline & & \multicolumn{2}{|c|}{ Pimbwe $(n=98)$} & \multicolumn{2}{|c|}{ Sukuma $(n=90)$} & \multicolumn{2}{|c|}{ Overall $(n=188)$} \\
\hline & & yes & no & yes & no & yes & no \\
\hline \multirow[t]{2}{*}{ KNP services } & yes & $4.1(4)$ & $65.3(64)$ & $1.1(1)$ & $17.8(16)$ & $2.7(5)$ & $42.5(80)$ \\
\hline & no & $21.4(21)$ & $9.2(9)$ & $68.9(62)$ & $12.2(11)$ & $44.2(83)$ & $10.6(20)$ \\
\hline \multirow[t]{2}{*}{ KNP visits } & yes & $21.4(21)$ & $66.3(65)$ & $34.4(31)$ & $21.1(19)$ & $27.7(52)$ & $44.7(84)$ \\
\hline & no & $4.1(4)$ & $8.2(8)$ & $35.6(32)$ & $8.9(8)$ & $19.1(36)$ & $8.6(16)$ \\
\hline \multirow[t]{2}{*}{ Wildlife conflicts } & yes & $14.3(14)$ & $48.0(47)$ & $43.3(39)$ & $16.7(15)$ & $28.2(53)$ & $33.0(62)$ \\
\hline & no & $11.2(11)$ & $26.5(26)$ & $26.7(24)$ & $13.3(12)$ & $18.6(35)$ & $20.2(38)$ \\
\hline
\end{tabular}

Table 4), with Pimbwe expressing a stronger tendency than Sukuma to recognize KNP visits $\left(\chi^{2}=25.330\right.$, d.f. $=1, \mathrm{P}<0.001)$. Table 5 lists the reasons given for KNP staff visits.

Respondents in the 2001 interviews were also asked about the type and extent of wildlife-related problems. Sixty-two percent $(n=125$; Pimbwe $=66$, Sukuma $=59)$ said they had experienced some form of wildlife-related problem, while $38 \%(n=76$; Pimbwe $=40$, Sukuma $=36)$ said they had not; crop destruction was cited as the main problem. There was no association between ethnicity and wildlife-related problems $\left(\chi^{2}=0.076\right.$, d.f. $=1$, $\mathrm{P}=0.783$ ), nor between wildlife-related problems and attitude towards $\mathrm{KNP}\left(\chi^{2}=0.104\right.$, d.f. $=1, \mathrm{P}=0.747$; Table 4), despite the relatively common occurrence of wildlife-related crop damage.

\section{Socioeconomic status and community attitudes}

Among surveyed households, variation in material wealth was not significantly associated with interest in seeing KNP degazetted $(n=188$, Mann-Whitney $U=4112.5$, $\mathrm{P}=0.439)$, although land ownership was $(\mathrm{n}=188$, MannWhitney $U=3362.5, P=0.005)$. Households owning greater amounts of land were more likely to express an interest in seeing KNP degazetted. Length of residency

Table 5 Reasons reported by the Pimbwe and Sukuma ethnic groups for why Katavi National Park staff visited their villages.

\begin{tabular}{lccc}
\hline Reasons for KNP staff visits & Pimbwe \% $(\mathrm{n}=93)$ & Sukuma \% $(\mathrm{n}=53)$ & Overall \% $(\mathrm{n}=146)$ \\
\hline Buying personal supplies & 35.5 & 15.1 & 28.1 \\
Just to relax & 24.7 & 28.3 & 26.0 \\
No idea why they visited & 9.7 & 26.4 & 15.8 \\
Organize village meetings & 14.0 & 3.8 & 10.3 \\
Drink alcohol and sleep with women & 5.4 & 0.0 & 8.9 \\
Educate the villagers about KNP & 6.5 & 5.7 & 4.1 \\
Gather information on poachers & 2.2 & 1.9 & 3.4 \\
Check on the status/condition of services & 1.1 & 3.8 & 1.4 \\
Sell poached meat & 0.0 & 0.0 & 1.4 \\
Hire day labourers & 1.1 & & 0.7 \\
\end{tabular}


was also associated with attitude towards $\mathrm{KNP}(\mathrm{n}=188$, Mann-Whitney $U=3208.5, \mathrm{P}=0.001$ ), with short-term residents more likely to express an interest seeing KNP degazetted. However, both greater land ownership and shorter residency times are characteristic of the Sukuma, whose generally more negative attitudes towards KNP have already been identified. Thus, to identify the relative effects of these factors as well as the previously identified effects of outreach factors on community attitudes, ethnicity must be considered.

\section{Explanatory model of attitudes towards Katavi National Park}

To test whether the relative effects of outreach and socioeconomic factors on attitude towards KNP fall away after controlling for ethnicity, and to determine the explanatory power of KNP outreach and household socioeconomic factors on attitudes towards KNP, an explanatory model using logistic regression was generated. The model explained $68 \%$ of the variation in respondents' interest in seeing KNP degazetted. Of all variables and interactions included in the model, only recognition of some form of KNP outreach service(s) had significant explanatory power $(\mathrm{P}<0.001$; Table 6$)$. The model estimated the odds of expressing interest in seeing KNP degazetted to be $99 \%$ higher for respondents not recognizing some form of outreach service.

\section{Associations between attitudes and resource use}

Compared with the Pimbwe, Sukuma respondents were more likely to express an interest in seeing KNP degazetted, less likely to recognize KNP services, and less likely to recognize KNP visits to their villages. As predicted, Sukuma should therefore exhibit less conservative resource use behaviours. Sukuma households did fell live trees and/or collect live branches more frequently than Pimbwe $\left(\chi^{2}=23.586\right.$, d.f. $=1$, $\left.\mathrm{P}<0.001\right)$; $79 \%$ of Sukuma exhibited such behaviour compared to only $15 \%$ of Pimbwe. Alternatively, respondents recognizing KNP services, and therefore more likely to express disinterest in seeing KNP degazetted (Table 6), came from households significantly more likely to collect dead fallen branches, or collect from dead trees $\left(\chi^{2}=10.245\right.$, d.f. $=1, P=0.001$; Table 7). This association held even when controlling for ethnicity (Wald $\chi^{2}=6.076$, d.f. $=1, P=0.014)$

\section{Discussion}

KNP outreach had a strong positive association with attitudes towards the Park; both recognition of KNP services and recognition of visits by KNP staff were clearly associated with a disinterest in seeing KNP degazetted, but were greatly influenced by ethnicity. While these findings corroborate those from similar studies, namely that protected area outreach seems pivotal in shaping positive conservation attitudes, they also demonstrate that recognition of outreach can vary greatly within communities.

The data also support the prediction that positive conservation attitudes are reflected in more conservationoriented behaviours. However, the value of this finding must be qualified by recognizing potential limitations, namely identifying wood use as a manifestation of conservation attitude; residents may not think of local

Table 6 Binomial logistic regression model of ethnicity, KNP outreach, demographic and socio-economic variables, and interaction terms with ethnicity, that influence an individual's interest in seeing Katavi National Park degazetted $(n=188$, d.f. $=12,-2$ log likelihood $=127.25)$. The direction of each binomial factor is indicated in parenthesis, with the sign of the coefficients showing whether the value is positive or negative.

\begin{tabular}{|c|c|c|c|c|c|c|c|}
\hline Factors & d.f. & B & S.E. & Wald $X^{2}$ & $\mathrm{P}$ & $\operatorname{Exp}(B)$ & 95\% C.I. \\
\hline Ethnicity (Pimbwe) & 1 & 0.429 & 1.668 & 0.066 & 0.797 & 1.535 & $0.058-40.392$ \\
\hline Recognized KNP service (no) & 1 & -4.296 & 0.818 & 27.564 & $<0.001$ & 0.014 & $0.003-0.068$ \\
\hline Recognized KNP visit (no) & 1 & -0.661 & 0.959 & 0.474 & 0.491 & 0.517 & $0.079-3.387$ \\
\hline $\begin{array}{l}\text { Experienced wildlife related } \\
\text { problems (no) }\end{array}$ & 1 & -0.396 & 0.502 & 0.623 & 0.430 & 0.673 & $0.251-1.800$ \\
\hline Years in the area & 1 & 0.024 & 0.023 & 1.054 & 0.304 & 1.024 & $0.979-1.071$ \\
\hline Material wealth & 1 & 0.082 & 0.051 & 2.548 & 0.110 & 1.086 & $0.981-1.201$ \\
\hline Land wealth & 1 & -0.205 & 0.163 & 1.594 & 0.207 & 0.814 & $0.592-1.120$ \\
\hline Ethnicity ${ }^{*} \mathrm{KNP}$ service & 1 & -0.427 & 1.398 & 0.093 & 0.760 & 0.652 & $0.042-10.105$ \\
\hline Ethnicity $*$ KNP visit & 1 & 0.719 & 1.157 & 0.386 & 0.534 & 2.052 & $0.213-19.822$ \\
\hline Ethnicity ${ }^{*}$ years in region & 1 & -0.019 & 0.053 & 0.128 & 0.721 & 0.981 & $0.885-1.088$ \\
\hline Ethnicity * Material wealth & 1 & -0.096 & 0.065 & 2.193 & 0.139 & 0.909 & $0.801-1.031$ \\
\hline Ethnicity * Land wealth & 1 & 0.227 & 0.164 & 1.913 & 0.167 & 1.255 & $0.909-1.733$ \\
\hline Constant & 1 & 1.298 & 1.408 & 0.850 & 0.357 & 3.661 & \\
\hline
\end{tabular}


Table 7 Association between recognition of village-level services received and frequency of exhibited fuelwood extraction method.

\begin{tabular}{|c|c|c|c|c|c|c|}
\hline & \multicolumn{6}{|c|}{ Recognition of KNP services? \% (n) } \\
\hline & \multicolumn{2}{|c|}{ Pimbwe $(n=33)$} & \multicolumn{2}{|c|}{ Sukuma $(n=39)$} & \multicolumn{2}{|c|}{ Overall $(n=72)$} \\
\hline & yes & no & yes & no & yes & no \\
\hline Extract dead trees and/or branches & $66.6(22)$ & $18.2(6)$ & $12.8(5)$ & $17.9(7)$ & $37.5(27)$ & $18.0(13)$ \\
\hline Extract live trees and/or branches & $6.1(2)$ & $9.1(3)$ & $20.5(8)$ & $48.8(19)$ & $13.9(10)$ & $30.6(22)$ \\
\hline
\end{tabular}

wood use, collected outside KNP, in the same domain as they do KNP itself. This supposition, however, ignores the complex nature of socioecological systems in rural society. Residents of the Rukwa Valley, like those of all rural African communities, are intimately tied to their environment, and a national park in the immediate area represents lost opportunities on many fronts, including wood extraction. This is coupled with the fact that the behaviour measured, namely extract dead versus live wood, reflects a conscious choice and therefore is more reflective of conservation effort.

Attitudes towards a protected area are shaped by individual and community perceptions, which are affected by type and degree of interaction between community members and protected area staff (Newmark et al., 1993; Fiallo \& Jacobson, 1995; Ite, 1996). Providing village-level services (e.g. school, health, and/or water services) is one way managers hope to demonstrate the value of a protected area to local communities; the presence or absence of such services often influences community attitudes (Ite, 1996; Mehta \& Kellert, 1998; Songorwa, 1999; Infield \& Namara, 2001). Local residents may also express positive attitudes towards a protected area while having negative attitudes towards protected area staff (Infield, 1988; Parry \& Campbell, 1992; Newmark et al., 1993; Nepal \& Weber, 1995). Such negative attitudes can be reinforced as a result of previous confrontational encounters with protected area staff and/or a perceived lack of respect for community concerns. Increased personal contact, carried out in good faith, therefore becomes critical to the development of understanding and trust between protected area staff and local residents (Hough, 1988).

In the study villages both village-level services and visits by KNP staff were important in shaping community attitudes. However, the manner in which these outreach efforts were recognized, and the degree to which recognition was influenced by ethnicity deserves consideration. While the most commonly recognized outreach services related to tangible benefits, benefits relating to resource protection were also commonly reported (Table 3); 38\% of respondents identified some form of resource protection as a service provided by KNP. However, the type of service recognized varied considerably along ethnic lines with more Pimbwe recognizing village-based services, and more Sukuma recognizing resource protection services (Table 3). Also, while recognition of KNP staff visits was associated with a positive attitude towards $\mathrm{KNP}, 54 \%$ of respondents said that KNP staff visited their village for personal reasons (Table 4). The figure increases to $70 \%$ when the response "no idea why they visited" is included. This lends support to the argument that visits by protected area staff do not always have to be in an official capacity in order to be influential, and that even informal visits can have positive impacts on community perceptions about protected areas and their staff (Newmark et al., 1993).

That Pimbwe and Sukuma varied significantly in their recognition of both village-level services and KNP staff visits is most likely a direct result of settlement patterns, and indirectly related to cultural differences. Pimbwe households are tightly clustered and situated close to the main road passing through the villages. Sukuma households lie much further from the village centre, often at distances $>5 \mathrm{~km}$. This settlement pattern makes interacting with KNP staff, and thus recognizing staff visits, much more likely for Pimbwe than Sukuma, with the probable result of improved relations between the Pimbwe and KNP staff (see Hough, 1988). Also, Sukuma households are somewhat autonomous; their economies, which revolve around keeping cattle and large-scale cultivation, produce complex interdependencies among Sukuma households. As a result, they interact much more with each other than with the more centrally located Pimbwe, and are thus less likely to recognize KNP outreach oriented towards centralized village services.

That reports of wildlife-related crop damage, although common in the study area, were not associated with attitudes towards KNP may result from the animal species commonly identified as causing crop damage. Of those species identified, elephants Loxodonta africana, warthogs Phacochoerus aethiopicus and vervet monkeys Cercopithecus aethiops (C. Holmes, unpub. data), only 
elephants are largely confined within KNP, and their crop damage is limited to the wet season. Warthogs and vervet monkeys, however, are common residents in the Open Area separating KNP from the villages, and opportunistically raid crop fields throughout the year. Crop raiding vervet monkeys, and occasional yellow baboons Papio cynocephalus, also descend from the escarpment bordering the villages to the south. As such, residents are more likely to associate these commonly occurring species with wildlife-related crop damage, and therefore less likely to hold the Park or its staff responsible.

In this study system, households not recognizing any form of village-level service from KNP, and therefore more likely to express an interest in seeing the Park degazetted, exhibited less sustainable wood extraction methods. This suggests that community attitudes may be used to shape future KNP community outreach initiatives. The relative influence of ethnicity suggests that such initiatives should initially focus on exploring new avenues of communication with the Sukuma. Unlike their Pimbwe counterparts, the Sukuma have been largely unreceptive to KNP outreach and exhibit less ecologically sustainable wood extraction methods. Consequently, Sukuma represent a substantial greater ecological threat outside the Park; the nature of this threat echoes the growing realization that conservation needs to extend beyond protected area boundaries into the surrounding landscape (Western, 2001; Sanderson et al., 2002).

Attitudinal studies seem to be a logical step towards making informed decisions about the utility of protected area outreach. However, as this study shows, while community outreach initiatives can be effective in shaping attitudes towards conservation, relating such outreach to behavioural changes in resource use through attitudinal assessment is a challenge that requires a clear understanding of the relative influence of various social, economic and cultural factors. Thus, understanding the circumstances under which attitudes accurately reflect behaviour is necessary if the utility of such studies is to be anything more than provisional.

\section{Acknowledgements}

Funding for this research came from the National Science Foundation (Grant \# BCS-0001886), and the University of California, Davis. Research permission was issued by the Tanzanian Commission of Science and Technology. I thank Monique Borgerhoff Mulder, Tim Caro, and three anonymous reviewers for their comments on earlier versions of this paper. Also, I am grateful to Beni Myala and Michael Sungula for their assistance in the field, and to the Pimbwe and Sukuma families who patiently answered my questions.

\section{References}

Abbot, J.I.O., Thomas, D.H.L., Gardner, A.A., Neba, S.E. \& Khen, M.W. (2001) Understanding the links between conservation and development in the Bamenda Highlands, Cameroon. World Development, 29, 1115-1136.

Adams, W.M. \& Hulme, D. (2001) Conservation and community: changing narratives, policy and practice in African conservation. In African Wildlife and Livelihoods: The Promise and Performance of Community Conservation (eds D. Hulme \& M. Murphree), pp. 9-23. James Currey, Oxford, UK.

Adams, W.M. \& Hulme, D. (2001) If community conservation is the answer in Africa, what is the question? Oryx, 35, 93-200.

Adams, W.M. \& Infield, M. (2001) Park outreach and gorilla conservation: Mgahinga Gorilla National Park, Uganda. In African Wildlife and Livelihoods: The Promise and Performance of Community Conservation (eds D. Hulme \& M. Murphree), pp. 131-147. James Currey, Oxford, UK.

Akama, J.S., Lant, C.L. \& Burnett, G.W. (1995) Conflicting attitudes toward state wildlife conservation programs in Kenya. Society and Natural Resources, 8, 133-144.

Alpert, P. (1996) Integrated conservation and development projects: examples from Africa. Bioscience, 46, 845-855.

Barrett, C.B. \& Arcese, P. (1995) Are integrated conservationdevelopment projects (ICDPs) sustainable on the conservation of large mammals in Sub-Saharan Africa? World Development, 23, 1073-1084.

Barrett, C.B. \& Arcese, P. (1998) Wildlife harvest in integrated conservation and development projects: linking harvest to household demand, agricultural production, and environmental shocks in the Serengeti. Land Economics, 74, 449-465.

Brandsrtöm, P. (1986) Who is a Sukuma and who is a Nyamwezi ethnic identity in west-central Tanzania. Working Papers in African Studies, 27, 1-15.

Caro, T.M. (1999a) Abundance and distribution of mammals in Katavi National Park, Tanzania. African Journal of Ecology, 37, 305-313.

Caro, T.M. (1999b) Densities of mammals in partially protected areas: the Katavi ecosystem of Western Tanzania. Journal of Applied Ecology, 36, 205-217.

De Boer, W.F. \& Baquete, D.S. (1998) Natural resource use, crop damage and attitude of rural people in the vicinity of the Maputo Elephant Reserve, Mozambique. Environmental Conservation, 25, 208-218.

Fiallo, E.A. \& Jacobson, S.K. (1995) Local communities and protected areas: attitudes of rural residents towards conservation and Machalilla National Park, Ecuador. Environmental Conservation, 22, 241-249.

Gibson, C.C. \& Marks, S.A. (1995) Transforming rural hunters into conservationists: an assessment of community-based wildlife management programs in Africa. World Development, 23, 941-957.

Gillingham, S. \& Lee, P.C. (1999) The impact of wildlife-related benefits on the conservation attitudes of local people around the Selous Game Reserve, Tanzania. Environmental Conservation, 26, 218-228.

Hackel, J.D. (1999) Community conservation and the future of Africa's wildlife. Conservation Biology, 13, 726-734. 
Heinen, J.T. (1993) Park-people relations in Kosi Tappu Wildlife Reserve, Nepal: a socio-economic analysis. Environmental Conservation, 20, 25-34.

Hough. J.L. (1988) Obstacles to effective management of conflicts between national parks and surrounding human communities in developing countries. Environmental Conservation, 5, 129-136.

Hulme, D. \& Murphree, M. (1999) Communities, wildlife and the 'new conservation' in Africa. Journal of International Development, 11, 277-285.

Hulme, D. \& Murphree, M. (eds) (2001) African Wildlife and Livelihoods: The Promise and Performance of Community Conservation. James Currey, Oxford, UK.

Inamdar, A., de Jode, H., Lindsay, K. \& Cobb, S. (1999) Capitalizing on nature: protected area management. Science, 283, 1856-1857.

Infield, M. (1988) Attitudes of a rural community towards conservation and a local conservation area in Natal, South Africa. Biological Conservation, 45, 21-46.

Infield, M. \& Namara, A. (2001) Community attitudes and behaviour towards conservation: an assessment of a community conservation programme around Lake Mburo National Park, Uganda. Oryx, 35, 48-60.

Ite, U.E. (1996) Community perceptions of the Cross River National Park, Nigeria. Environmental Conservation, 23, 351-357.

Kirk, R.E. (1995) Experimental Design: Procedures for the Behavioral Sciences. Brooks/Cole, California, USA.

Kiss, A. (1990) Living with Wildlife: Wildlife Resource Management with Local Participation in Africa. The World Bank, Washington, DC, USA.

Kothari, A. (2001) Time to move Out of Africa! - A Response to Adams and Hulme. Oryx, 35, 204-205.

Mehta, J.A. \& Heinen, J.T. (2001) Does community-based conservation shape favorable attitudes among locals? An empirical study from Nepal. Environmental Conservation, 28, 165-177.

Mehta, J.A. \& Kellert, S.R. (1998) Local attitudes toward community-based conservation policy and programmes in Nepal: a case study in the Makalu-Barun conservation area. Environmental Conservation, 25, 320-333.

Morris, S., Carletto, C., Hoddinott, J. \& Christiaensen, L.J.M. (1999) Validity of Rapid Estimates of Household Wealth and Income for Health Surveys in Rural Africa. Discussion Paper No. 72, International Food Policy Research Institute, Washington, DC, USA.

Nepal, S.K. \& Weber, K.E. (1995) Prospects for coexistence: wildlife and local people. Ambio, 24, 238-245.

Newmark, W.D., Leonard, N.L., Sariko, H.I. \& Gamassa, D.M. (1993) Conservation attitudes of local people living adjacent to five protected areas in Tanzania. Biological Conservation, 63, 177-183.

Newmark, W.D. \& Hough, J.L. (2000) Conserving wildlife in Africa: integrated conservation and development projects and beyond. BioScience, 50, 585-592.

Noss, A.J. (1997) Challenges to nature conservation with community development in Central African forests. Oryx, 31, 180-188.

Noss, A.J. \& Cuéllar, R.L. (2001) Community attitudes towards wildlife management in the Bolivian Chaco. Oryx, 35, 292-300.
Oates, J.F. (1995) The danger of conservation by rural development: a case study from the forests of Nigeria. Oryx, 29, 115-122.

Oates, J.F. (1999) Myth and Reality in the Rain Forest: How Conservation Strategies are Failing in West Africa. University of California Press, Berkeley, USA.

Oli, M.K., Taylor, I.R. \& Rogers, M.E. (1994) Snow leopard Panthera unica predation of livestock: an assessment of local perceptions in the Annapurna Conservation Area, Nepal. Biological Conservation, 68, 63-68.

Paciotti, B. \& Hadley, C. (in press) The ultimatum game among sympatric tribes in southwestern Tanzania: ethnic variation and institutional scope. Current Anthropology.

Parry, D. \& Campbell, B. (1992) Attitudes of rural communities to animal wildlife and its utilization in Chobe Enclave and Mababe Depression, Botswana. Environmental Conservation, $19,245-252$.

Rodgers, W.A. (1996) The miombo woodlands. In East African Ecosystems and Their Conservation (eds T.R. McClanahan \& T.P. Young), pp. 299-325. Oxford University Press, New York, USA.

Sanderson, E.W., Redford, K.H., Vedder, A., Coppolillo, P.B. \& Ward, S.E. (2002) A conceptual model for conservation planning based on landscape species requirements. Landscape and Urban Planning, 58, 41-56.

Songorwa, A.N. (1999) Community-based wildlife management (CWM) in Tanzania: are the communities interested? World Development, 27, 2061-2079.

Tanzania. (1991) Rukwa Region Statistics Abstract, 1991. Planning Commission, Regional Statistical Office, Sumbawanga, Tanzania.

Wells, M., Brandon, K. \& Hannah, L. (1992) People and Parks: Linking Protected Area Management with Local Communities. The World Bank, Washington, DC, USA.

Western, D. (2001) Taking the broad view of conservation: a response to Adams and Hulme. Oryx, 35, 201-203.

Western, D. \& Wright, M. (eds.) (1994) Natural Connections: Perspectives in Community-based Conservation. Island Press, Washington, DC, USA.

Willis, R.G. (1966) The Fipa and Related Peoples of South-west Tanzania and North-east Zambia. International African Institute, London, UK.

\section{Biographical sketch}

Christopher Holmes' research interests include interactions between rural communities and protected areas, and examining decision-making patterns of rural communities towards resource use and factors associated with intra- and inter-community variation. He has been working with the communities south of Katavi National Park since 1998, and is now coordinating socioeconomic research for a biodiversity project around Ranomafana National Park, Madagascar.

\section{Appendices 1-2}

The appendices for this article are available online at http://journals.cambridge.org 